\title{
Bead-on-Plate Underwater Wet Welding on S700MC Steel
}

\author{
Jacek Tomków ${ }^{1 *}$, Aleksandra Świerczyńska' ${ }^{1}$, Michał Landowski', \\ Adrian Wolski', Grzegorz Rogalski' \\ 1 Faculty of Mechanical Engineering and Ship Technology, Gdańsk University of Technology, G. Narutowicza \\ 11/12, 80-233 Gdańsk, Poland \\ * Corresponding author's email: jacek.tomkow@pg.edu.pl
}

\begin{abstract}
The participation of high strength steels in marine and offshore structures is increasing, which makes it necessary to develop recommendations for underwater repair welding works. The article presents the results of bead-on-plate welded specimens made of S700MC high strength steel in underwater wet welding conditions by covered electrodes. Three specimens with heat input values in the range $0.91-1.05 \mathrm{~kJ} / \mathrm{mm}$ were made. The specimens were subjected to visual, metallographic, macro- and microscopic tests as well as hardness measurements using the Vickers method. It was found that the higher heat input leads to formation of mixed bainite-martensite microstructure in the heat-affected zone (HAZ). Lower heat input value results in presence of martensite in HAZ. It was shown that in the scope of the performed tests, the maximum hardness of HAZ did not exceed the critical value for the material group, and the increase in heat input caused the decrease of hardness by about 25 HV10 to a level 250-260 HV10.
\end{abstract}

Keywords: underwater wet welding, MMA welding, high-strength steel, covered electrodes.

\section{INTRODUCTION}

Underwater works can be divided into two main groups: fabrication of structures and repair (maintenance) works $[1 \div 3]$. In both cases, different technologies are used: joining, cutting, fastening, bolting, concreting, cleaning, applying protective layers and inspections $[4 \div 6]$. The growing number of aging (with exceeded service life) ocean and offshore structures necessitates obtaining data for the development of guidelines for the implementation of these works. Among the underwater processes, welding processes play a significant role [7, 8]. Three main groups of underwater welding methods are distinguished: dry welding, local cavity welding and wet welding. Dry welding is carried out in special chambers, which isolate welder and all welding area from environment [9]. The cost of designing and making such chambers is very high, but the quality of the joints is similar to those made in air environment. The second method - local cavity welding, uses special chamber of limited size and isolate from water only small welding area [10]. The welded joint is not covered by the chamber during the entire cooling process, and the water affects its properties, causing e.g. unfavorable transformations in the solid state. Wet welding carried out directly in water is the least expensive and is still the most popular method of underwater welding $[11,12]$. The basic advantages determining the popularity of wet welding include: low cost due to the lack of the need to use a chamber and no restriction of the welder diver's operability [13].

Water environment generates some important weldability problems. From the technological point of view, the most important are limited visibility and instability of welding arc, which is generated by the pressure generated by surrounding environment and the presence of gas bubbles and solid particles $[14,15]$. The most important problem generated by the water, is high susceptibility to cold cracking of welded steel. Cold cracks are commonly observed in the heat affected zone (HAZ), and run parallel to the fusion line. They could appear even 48 
$\mathrm{h}$ after welding process [16]. Cold cracks are caused by simultaneously presence of three factors: residual stresses [17, 18], brittle structures $[19,20]$ and high diffusible hydrogen content in deposited metal $[8,21 \div 23]$. All of mentioned factors are cumulated during underwater welding. According this, there is necessity of underwater welding investigations, which may results in decreasing the susceptibility to cold cracking of steels used for underwater structures.

Most of the investigations in the field of underwater wet welding are focused on the steels with yield point lower than $500 \mathrm{MPa}$ [10, 24, 25]. However, the usage of materials with higher mechanical properties is rising. High strength steels are commonly used for pressure vessels, road restraint systems, pipelines, ships, offshore structures and especially wind tubular jackets [ $26 \div 31]$. Many of mentioned structures may undergo failures in the water environment $[32,33]$, which necessitates their immersion repair [34, 35].

S700MC steel is a candidate material for heavily environmental stressed marine structures. Its high mechanical properties resulted from termomechanically process combined with influence of alloying micro-additions as $\mathrm{Nb}$, Ti and $\mathrm{V}$ [36]. The S700MC steel is characterized by an unbalanced, fine-grained bainitic-ferritic microstructure and is known as well weldable in the air environment

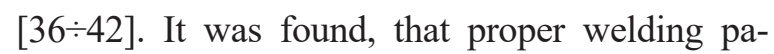
rameters allow to obtain good quality of S700MC steel joints welded in the air, as it was stated by Skowrońska et al. [42]. Szymczak et al. [43] proved that investigated material is very sensitive to the welding process. They stated that properties of S700MC welded joint are strongly influenced by welding parameters. Węgrzyn et al. [44] proved that increased cooling rate does not significantly decrease the properties of S700MC welded joints. It suggests that investigated steel could be tested in water environment in high-cooling rate conditions.

The aim of presented paper was to investigate the influence of heat input value on the properties of bead-on-plate welds on S700MC steel in wet welding conditions by Manual Metal Arc (MMA) welding.

\section{MATERIALS AND METHODS}

For investigations the S700MC steel plates with dimensions $10 \mathrm{~mm} \times 150 \mathrm{~mm} \times 100 \mathrm{~mm}$ were prepared. As a filler material the underwater rutile electrodes $4.0 \mathrm{~mm}$ diameter; nearest equivalent E42 2 1Ni RR 51 (following EN ISO 2560:2021) were chosen. The commonly used under water undermatched consumable was selected, because there are no electrodes on the market dedicated to underwater welding of high strength steels. Moreover, in previous investigations [24, 46] it was proved that used electrodes allow to perform good quality underwater structures. The chemical composition and mechanical properties of used materials are presented in Table 1 and Table 2.

For investigations three specimens were wet welded in tap water $\left(20^{\circ} \mathrm{C}\right)$ at $0.25 \mathrm{~m}$ depth, using the MMA (111) process. Bead-on-plate specimens welding was performed in the flat (PA) position with negative polarity (DC-) following the electrode manufacturer data with the usage of electrodes from the same package. Filler materials from different packages may generate different

Table 1. Chemical composition of used materials, wt. \%

\begin{tabular}{|l|c|c|c|c|c|c|c|c|c|c|}
\hline \multicolumn{1}{|c|}{ Material } & $\mathrm{C}$ & $\mathrm{Mn}$ & $\mathrm{Si}$ & $\mathrm{S}$ & $\mathrm{P}$ & $\mathrm{Al}$ & $\mathrm{Nb}$ & $\mathrm{Ti}$ & $\mathrm{V}$ & $\mathrm{Ce}_{\text {IIW }}{ }^{* * *}$ \\
\hline S700MC $^{*}$ & 0.058 & 1.68 & 0.16 & 0.005 & 0.01 & 0.027 & 0.044 & 0.12 & 0.006 & 0.34 \\
\hline $\begin{array}{l}\text { E42 2 1Ni RR 41 } \\
\text { electrode ** }\end{array}$ & 0.05 & 0.50 & 0.45 & - & 0.025 & -- & - & - & - & - \\
\hline
\end{tabular}

${ }^{*}$ - analysis by spark emission spectrometry, ${ }^{* *}$ - manufacturer data, ${ }^{* * *}$ - carbon equivalent by International Institute of Welding

Table 2. Mechanical properties of used materials following the manufacturer data

\begin{tabular}{|l|c|c|c|}
\hline \multicolumn{1}{|c|}{ Material } & $\begin{array}{c}\text { Yield point, } R_{e} \\
{[\mathrm{MPa}]}\end{array}$ & $\begin{array}{c}\text { Tensile strength, } \mathrm{R}_{\mathrm{m}} \\
{[\mathrm{MPa}]}\end{array}$ & $\begin{array}{c}\text { Elongation, } A_{5} \\
{[\%]}\end{array}$ \\
\hline S700MC* $^{*}$ & 768 & 822 & 19.0 \\
\hline $\begin{array}{l}\text { E42 2 1Ni RR 41 } \\
\text { electrode deposit** }\end{array}$ & - & 540 & 26.0 \\
\hline
\end{tabular}

* - analysis by spark emission spectrometry, ${ }^{* *}$ - manufacturer data 
properties of welded joints [45]. Each specimen was welded with different parameter values (in the range suggested by filler material manufacturer). It resulted in different values of heat input (qI) calculated as [12]:

$$
l=\frac{I \cdot U}{V w}
$$

The values of used heat input were chosen near $1 \mathrm{~kJ} / \mathrm{mm}$ following the previous investigations carried out on high-strength steels [24]. It was proved that mentioned heat values allow to perform wet welding process with the lowest instability of welding arc. Welding parameters are presented in Table 3.

After welding, specimens were subjected to non-destructive and destructive tests. Firstly, the visual test (VT) was carried out $48 \mathrm{~h}$ after specimen preparation following the requirements of EN ISO 17637:2017 standard. The $48 \mathrm{~h}$ time is required due to the susceptibility to forming cold cracks [16]. In the next step, from each specimen the cross-section from the middle part of weld bead was made. After cutting, specimens were ground, polished and etched by Nital (4\%). Then, the metallographic macro- (using Canon EOS 1200D camera) and microscopic (using Olympus BX51 light microscope) tests were performed following EN ISO 17639:2013 standard. The last step during investigations were Vickers HV10 hardness measurements (using Sinowon V-10 instrument) following the EN ISO 9015-1:2011 standard. The scheme of distribution points for hardness measurements is presented in Figure 1.

\section{RESULTS AND DISCUSSION}

During welding the instability of welding arc was observed, which is typical for wet welding process $[18 \div 20]$. This instability decreased with increasing heat input values. The results of welding process were observed during VT, and are presented in Figure 2. Based on the results of the VT, areas for further investigations were selected. However, some imperfections characteristic for underwater welding $[1,46]$ were observed. In Specimen 1 the open surface pore was detected (Fig. 2a). This pore was observed in area of the biggest instability of welding arc. Moreover, this region is characterized by smaller width of the weld, than in the rest of specimen. Pores were also detected near beginning of the Specimen 2 (Fig. 2b). Specimen 3, which was welded with the highest heat input is characterized by the best quality of the welds' face. However, shape defects and porosity in crater were observed (Fig. 2c). During VT the differences in bead width were observed. The bead width increased with increasing heat input. Specimens for further investigations were cut in areas without presence of the imperfections.

Table 3. Welding parameters

\begin{tabular}{|c|c|c|c|c|}
\hline Specimen no. & $\begin{array}{c}\text { Welding current, I } \\
{[\mathrm{A}]}\end{array}$ & $\begin{array}{c}\text { Arc voltage, U } \\
{[\mathrm{V}]}\end{array}$ & $\begin{array}{c}\text { Welding speed, Vw } \\
{[\mathrm{mm} / \mathrm{s}]}\end{array}$ & $\begin{array}{c}\text { Heat input, ql } \\
{[\mathrm{kJ} / \mathrm{mm}]}\end{array}$ \\
\hline 1 & 204 & 25.3 & 5.7 & 0.91 \\
\hline 2 & 224 & 27.5 & 6.5 & 0.96 \\
\hline 3 & 248 & 29.8 & 7.0 & 1.05 \\
\hline
\end{tabular}

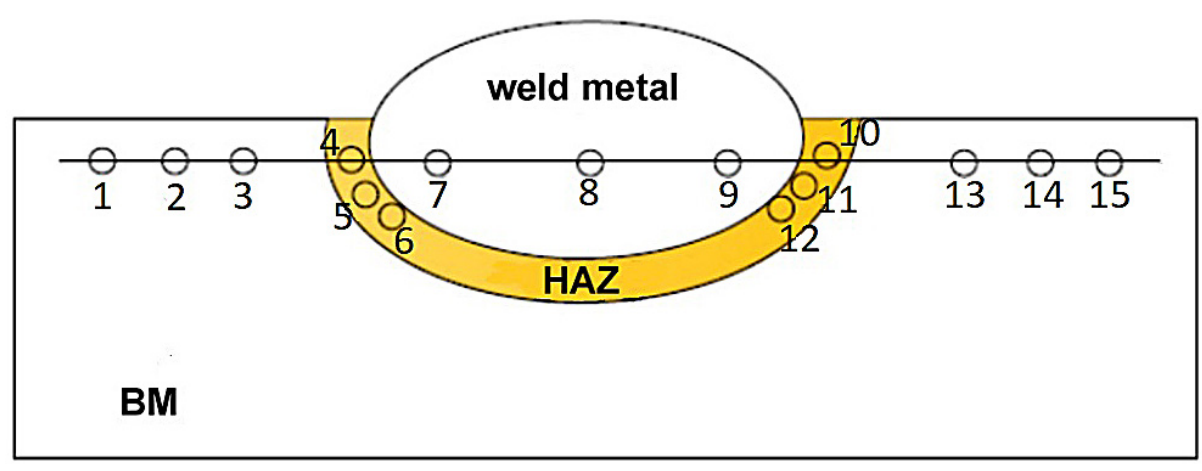

Fig. 1. Distribution points for hardness measurements 

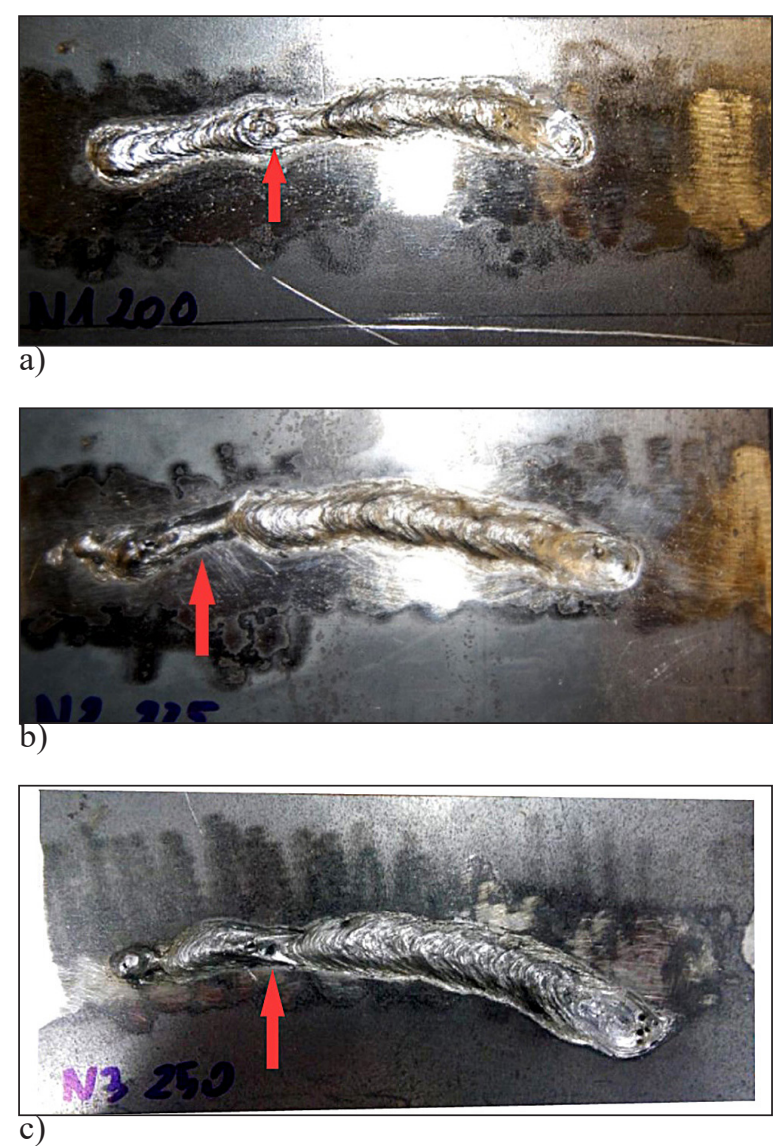

Fig. 2. Results of VT: a) Specimen 1 - pore, big shape defects, b) Specimen 2 - pore, big shape defects,

c) Specimen 3 - small shape defects, porosity in crater

In the next step, the metallographic macroscopic test was performed. The exemplary results are presented in Figure 3. There was no occurrence of cracks, the presence of which was reported in many studies concerning the weldability of steel under water $[13,24,46]$. However, the typical imperfection as undercut was observed in Specimen 2 (Fig. 3b). The macroscopic results proved that different heat input results in the changes in geometry of weld bead. With increasing heat input, the width of HAZ also increases. The same effect was observed for butt welding in the air by Njock Bayock et al. [47].

The microstructure of base metal (BM) is presented in Figure 4. Used S700MC high strength steel is characterized by mixed bainitic and ferritic microstructure, with a visible effect of the thermomechanical treatment process.

The exemplary micrographs showing the weld metal are presented in Figure 5. The dendritic structure of the welds in each case contained martensite (Figs. 5a-f). Dendrites are arranged with columns raising to the axis od performed

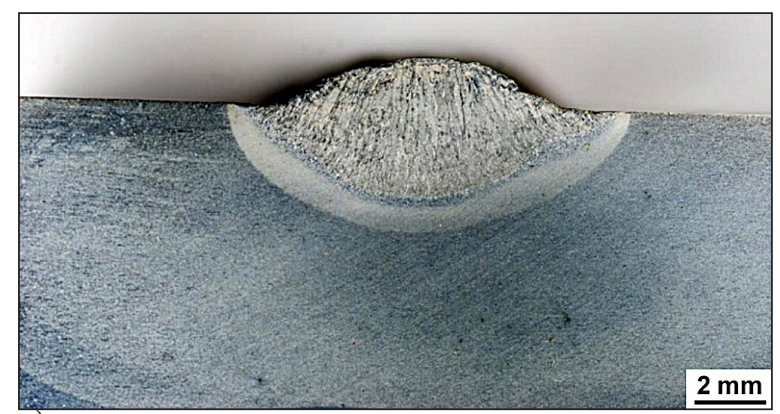

a)
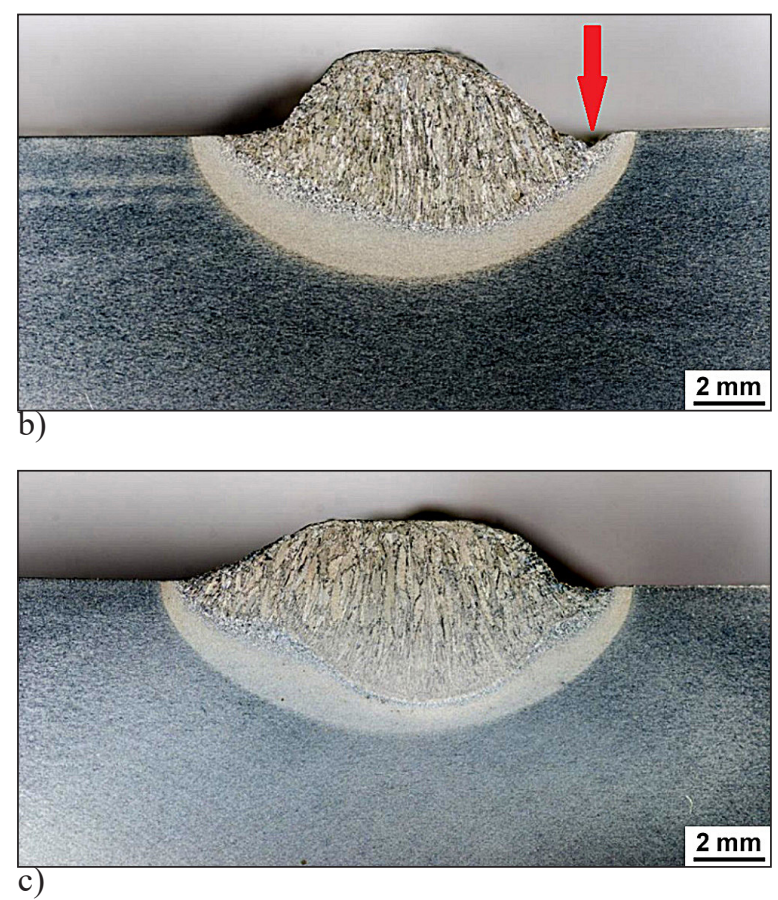

Fig. 3. Exemplary macrographs: a) Specimen 1,

b) Specimen 2 - undercut, c) Specimen 3

beads, which is typical for crystallization of molten metal during welding [48]. With the increase of heat input, the presence of bainite was observed (Figs. 5e and 5f). In Specimen 2 in weld metal the cracks were detected (Figs. 5c and 5d). The crack propagation path is typical for cracking phenomena in steels [13, 24, 46, 49].

The overheated zone was chosen for microscopic observations (Fig. 6) due to results observed in previous investigations [12, 13, 24]. In investigated region the cold cracks were detected. Performed investigations showed effect of heat input value on the microstructure in HAZ of bead-on-plate wet welded structured. The microstructure of Specimen 1 (q1 $=0.91 \mathrm{~kJ} / \mathrm{mm}$ ) consists martensite (Fig. 6a). With increasing heat input, the bainite could be observed (Figs. 6b and 6c). However, the highest content of bainite mixed with martensite was observed in specimen $3(\mathrm{ql}=1.05 \mathrm{~kJ} /$ 


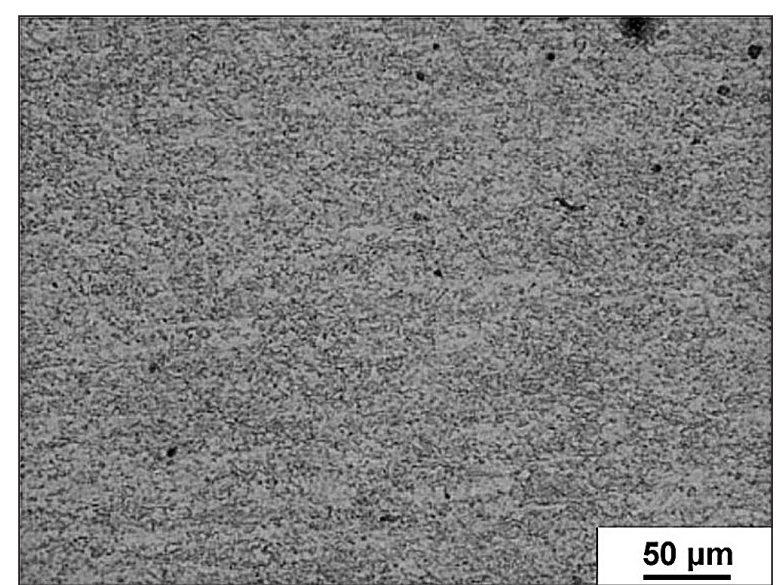

Fig. 4. Microstructure of S700MC steel

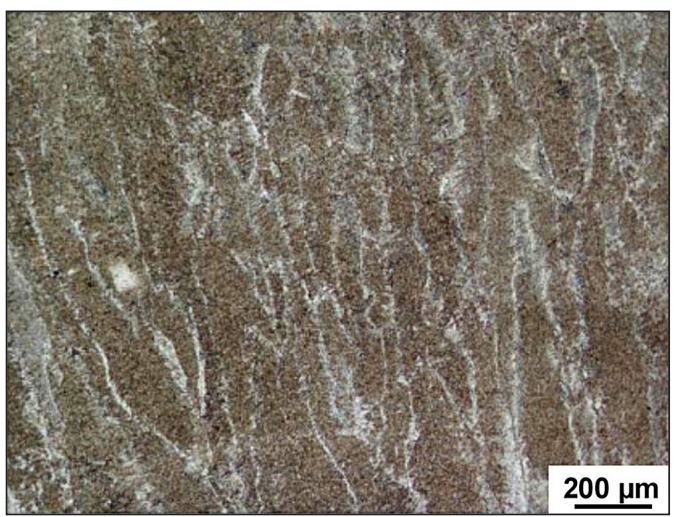

a)

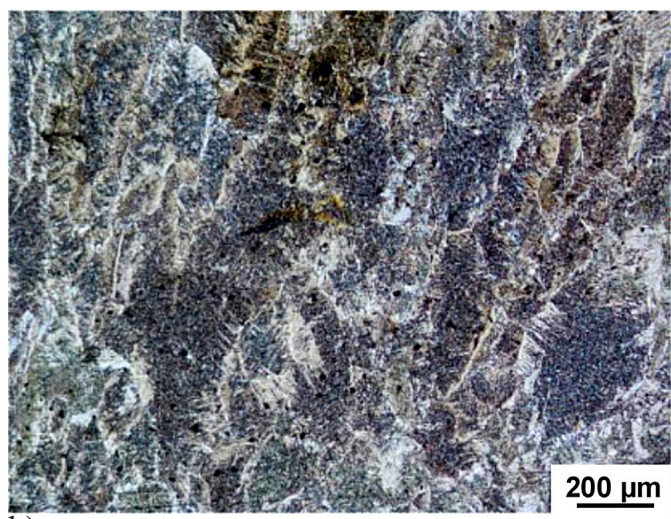

b)

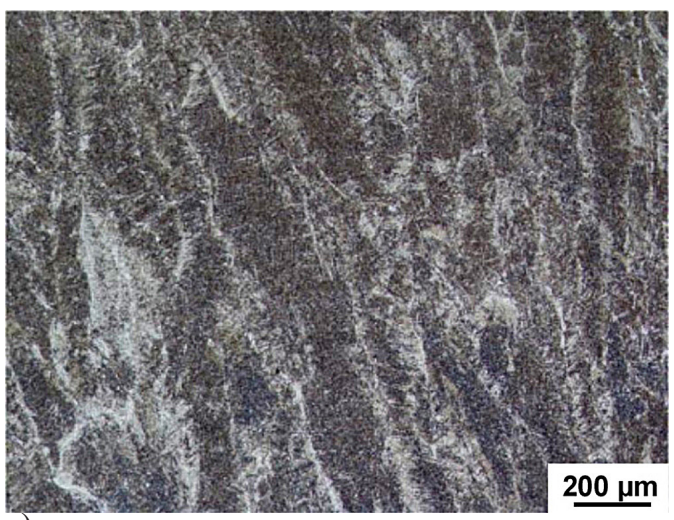

c) $\mathrm{mm})-$ Fig. 6c. It is worth noting that the HAZs of each specimen were free of cracks. It suggest that investigated S700MC steel could be used in wet welding conditions, but the development of guidelines for the wet welding procedure of this steel grade requires additional tests aimed at reducing the susceptibility of the weld to form cold cracks. The use of the temper bead welding technique can be considered particularly promising $[50,51]$.

Results of hardness measurements are presented in Figure 7. Hardness of wet welded joints strongly depends on the welding parameters, which was proved by Surojo et al. [52].
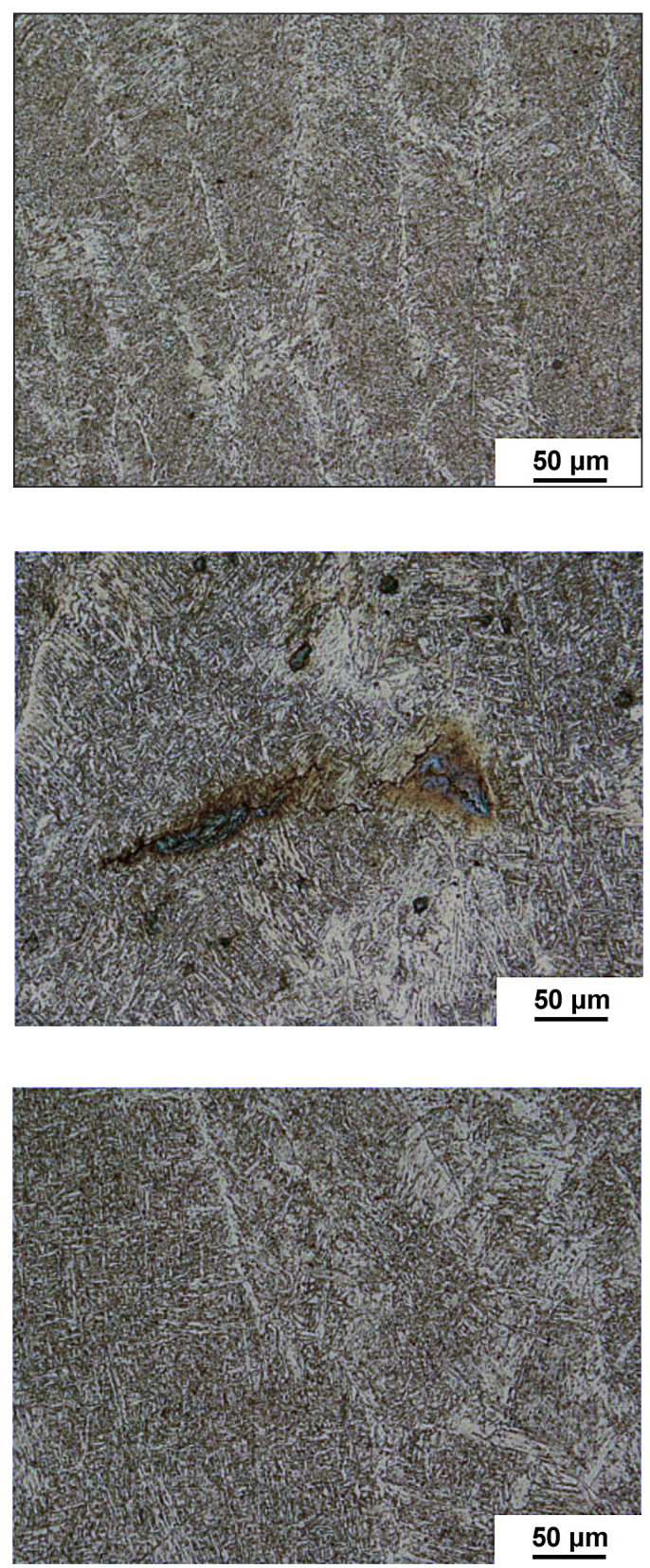

Fig. 5. Exemplary micrographs of weld metal: a) Specimen 1, b) Specimen 2 - cracks, c) Specimen 3 


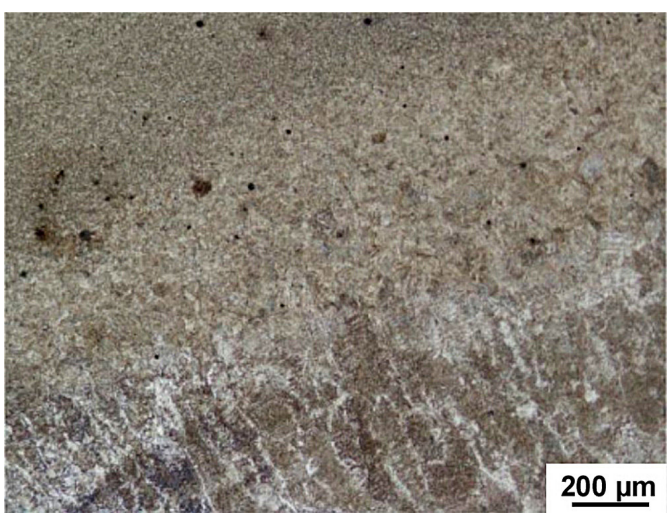

a)

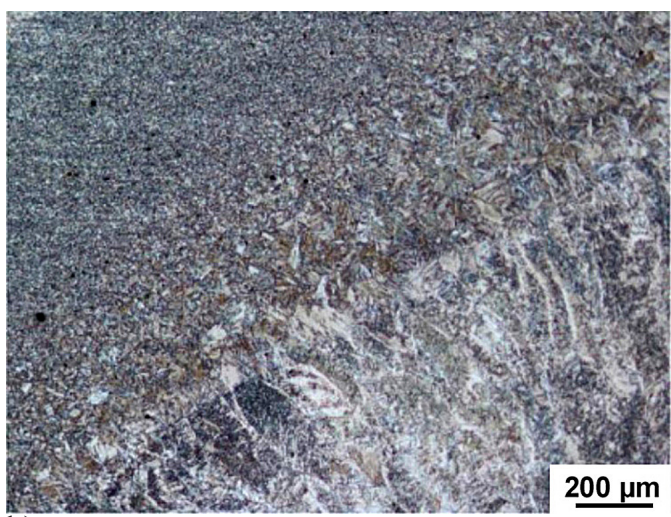

b)

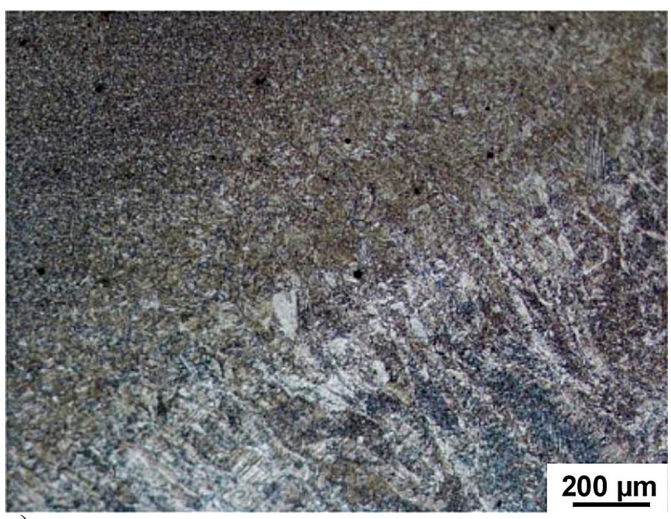

c)
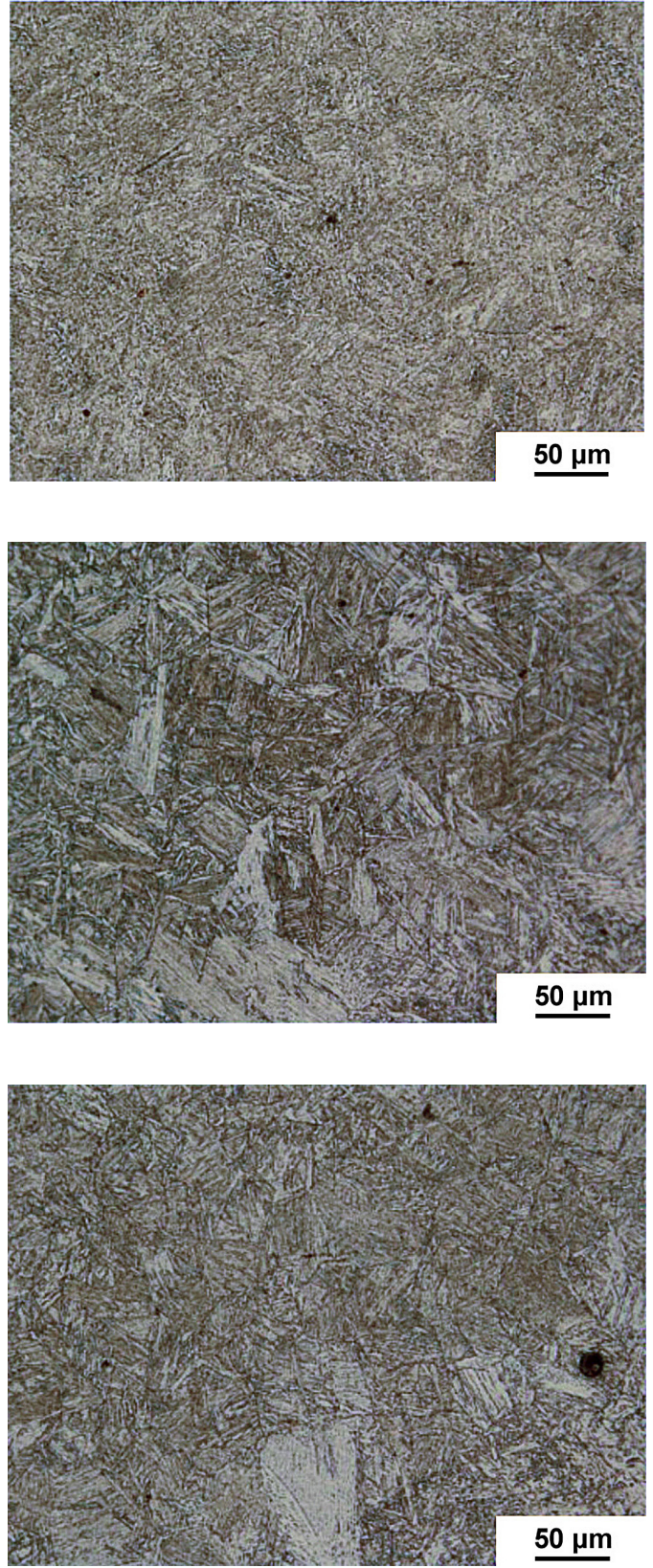

Fig. 6. Exemplary micrographs of HAZ: a) Specimen 1, b) Specimen 2, c) Specimen 3

They proved that hardness increase with increasing cooling rate. Similar results were observed in presented investigations. However, the increase in hardness is not large due to the low value of the carbon equivalent of the tested steel $\left(\mathrm{Ce}_{\mathrm{IIW}}=0.34\right)$. The maximum hardness of HAZ does not exceed the criterion recommended by the standards (maximum $380 \mathrm{HV} 10$ according to EN ISO 15614-1:2017). Welding with higher heat input value leads to reduction of the hardness of HAZ by about 25 HV10. It confirms results of microscopic observations. The lowest HAZ hardness were observed in
Specimen 3 welded with $1.05 \mathrm{~kJ} / \mathrm{mm}$, in which the mixture of martensite and bainite was detected. No significant influence of heat input on the weld metal hardness was observed. The hardness of weld metal is lower than BM hardness. It resulted from the presence of solidification microstructure consists coarse grains in weld metal, and fine-grained microstructure in $\mathrm{BM}$ created during metal forming process. The fine-grained microstructure is typical for highstrength steels [53]. Properties of weld mainly depends on the properties of deposited metal (consumable grade). 


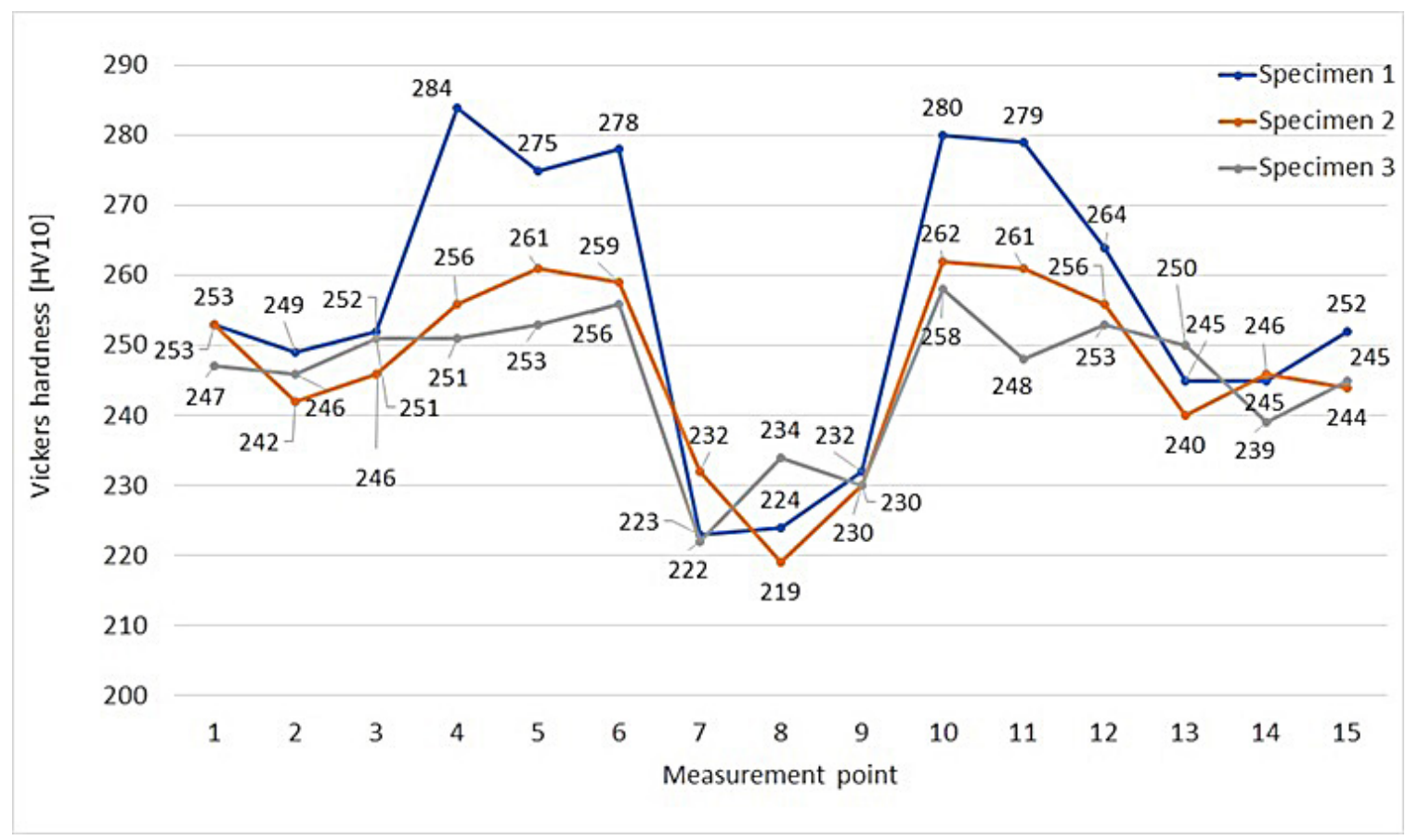

Fig. 7. Results of hardness measurements

\section{CONCLUSIONS}

The analysis carried out comparing properties of S700MC bead-on-plate wet welds performed with different heat input values allows to draw following conclusions:

1. S700MC steel can be successfully welded in the underwater wet welding conditions by undermatched covered electrodes. Surprisingly, no cold cracks were found in the HAZ in beadon-plate specimens.

2. Heat input value plays significant role during wet welding of S700MC steel. With increasing value of heat input, the hardness of overheated HAZ decreased (about 25 HV10) to a level 250-260 HV10. This is due to the influence of heat input value on allotropic changes resulting in differences in the volumetric shares of individual structures of the welded joint.

3. In underwater conditions the S700MC high strength steel should be welded with heat input higher than $1.05 \mathrm{~kJ} / \mathrm{mm}$. This allows to obtain the appropriate hardness of the HAZ structure and avoid cold cracks formation in all zones of the welded joint.

\section{REFERENCES}

1. Rogalski G., Fydrych D., Łabanowski J. Underwater wet repair welding of API 5L X65M pipeline steel. Polish Maritime Research. 2017;24(S1):188-194.
2. Wei P., Li H., Liu J., Li S., Zhang Y., Zhu Q., Lei Y. The effect of water environment on microstructural characteristics, compositional heterogeneity and microhardness distribution of $16 \mathrm{Mn} / 304 \mathrm{~L}$ dissimilar welded joints. Journal of Manufacturing Processes. 2020;56:417-427.

3. Wang Z.D., Sun G.F., Chen M.Z., Lu Y., Zhang S.B., Lan H.F., Bi K.D., Ni Z.H. Investigation of the underwater laser directed energy deposition technique for the on-site repair of HSLA-100 steel with excellent performance. Additive Manufacturing. 2021;39:101884.

4. Parshin S.G., Levchenko A.N., Wang P., Maystro A.S. Mathematical analysis of the influence of the flux-cored wire chemical composition on the electrical parameters and quality in the underwater wet cutting. Advances in Materials Science. 2021;21(1):77-89.

5. Zaidi F.H.A., Ahmad R., Abdullah M.M.A.B., Abd Rahim S.Z., Yahya Z., Li L.Y., Ediati R. Geopolymer as underwater concreting material: A review. Construction and Building Materials. 2021;291:123276.

6. George J.M., Kimiaei M., Elchalakani M., Fawzia S. Experimental and numerical investigation of underwater composite repair with fibre reinforced polymers in corroded tubular offshore structural members under concentric and eccentric axial loads. Engineering Structures. 2021;227:111402.

7. Dong S., Han Y., Jia C., Wu C., Zhang M., Yang Q., Yang J. Organic adhesive assisted underwater submerged-arc welding. Journal of Materials Processing Technology. 2020;284:116739. 
8. Tomków J., Fydrych D., Rogalski G., Łabanowski J. Effect of the welding environment and storage time of electrodes on the diffusible hydrogen content in deposited metal. Revista de Metalurgia. 2019;55(1):e140.

9. Sun K., Hu Y., Shi Y., Liao B. Microstructure evolution and mechanical properties of underwater dry welded metal of high strength steel Q690E under different water depths. Polish Maritime Research. 2020;27:112-119.

10. Tomków J., Janeczek A., Rogalski G., Wolski A. Underwater local cavity welding of S460N Steel. Materials. 2020;13:5535.

11. Fu Y., Guo N., Wang G., Yu M., Cheng Q., Zhang D. Underwater additive manufacturing of Ti-6Al$4 \mathrm{~V}$ alloy by laser metal deposition: Formability, gran growth and microstructure evolution. Materials \& Design. 2021;197:109196.

12. Tomków J., Janeczek A. Underwater in situ local heat treatment by additional stitches for improving the weldability of steel. Applied Sciences. 2020;10(5): 1823 .

13. Fydrych D., Łabanowski J., Rogalski G., Haras J., Tomkow J., Świerczyńska A., Jakóbczak P., Kostro Ł. Weldability of S500MC steel in underwater conditions. Advances in Materials Science. 2014;14:37-45.

14. Wang J., Sun Q., Ma J., Jin, P., Sun, T., Feng, J. Correlation between wire feed speed and external mechanical constraint for enhanced process stability in underwater wet flux-cored arc welding. Proceedings of the Institution of Mechanical Engineers, Part B: Journal of Engineering Manufacture. 2018;233:2061-2073.

15. Moreno-Uribe A.M., Bracarense A.Q., Pessoa E.C.P. The effect of polarity and hydrostatic pressure on operational characteristics of rutile electrode in underwater welding. Materials. 2020;13:5001.

16. Wilhelm E., Mente T., Rhode M. Waiting time before NDT of welded offshore steel grades under consideration of delayed hydrogen-assisted cracking. Welding in the World. 2021;65(5):947-959.

17. Schaupp T., Schroeder N., Schroepfer D., Kannengiesser T. Hydrogen-Assisted Cracking in GMA Welding of High-Strength Structural Steel-A New Look into This Issue at Narrow Groove. Metals. 2021;11(6):904.

18. Chen H., Guo N., Xu K., Liu C., Wang G. Investigating the advantages of ultrasonic-assisted welding technique applied in underwater wet welding by in-situ X-ray imaging method. Materials. 2020;13:1442.

19. Surojo E., Gumilang A.H., Triyono T., Prabowo A.R., Budiana E.P., Muhayat N. Effect of water flow on underwater wet welded A36 Steel. Metals. 2021;11:682.
20. Wang J., Liu Y., Feng J., Sun Q. Microstructure evolution of E40 steel weldments in ultrasonicwave-assisted underwater FCAW. Welding Journal. 2021;100:106-120.

21. Klett J., Wolf T., Maier H.J., Hassel T. The applicability of the standard DIN EN ISO 3690 for the analysis of diffusible hydrogen content in underwater wet welding. Materials. 2020;13:3750.

22. Klett J., Hassel T. Influence of stick electrode coating's moisture content on the diffusible hydrogen in underwater wet shielded metal arc welding. Advances in Materials Science. 2020;20:27-37.

23. Parshin S.G., Levchenko A.M., Maystro A.S. Metallurgical model of diffusible hydrogen and nonmetallic slag inclusions in underwater wet welding of high-strength steel. Metals. 2020;10:1498.

24. Tomków J. Weldability of underwater wet-welded HSLA steel: Effect of electrode hydrophobic coatings. Materials. 2021;14:1364.

25. Wang J., Ma J., Liu Y., Zhang T., Wu S., Sun Q. Influence of Heat Input on Microstructure and Corrosion Resistance of Underwater Wet-Welded E40 Steel Joints. Journal of Materials Engineering and Performance. 2020;29(11):6987-6996.

26. Braun M., Milaković A., Ehlers S., Kahl A., Willems T., Seidel M., Fischer C. Sub-zero temperature fatigue strength of butt-welded normal and highstrength steel joints for ships and offshore structures in arctic regions. Proceedings of the ASME 2020 39th International Conference on Ocean, Offshore and Arctic Engineering. 2020;3:V003T03A010.

27. Ali L., Khan S., Bashmal S., Iqbal N., Dai W., Bai Y. Fatigue crack monitoring of T-type joints in steel offshore oil and gas jacket platform. Sensors. 2021;21:3294.

28. Adumane S., Adedigba S., Khan F., Zendehboudi $\mathrm{S}$. An integrated dynamic failure assessment model for offshore components under microbiologically influenced corrosion. Ocean Engineering. 2020;218:108082.

29. Kumar S., Yadav V.K., Sharma S.K., Pandey C., Goyal A., Kumar P. Role of dissimilar Ni-based ERNiCrMo-3 filler on the microstructure, mechanical properties and weld induced residual stresses of the ferritic/martensitic P91 steel welds joint. International Journal of Pressure Vessels and Piping. 2021;193:104443.

30. Tuz L. Determination of the causes of low service life of the air fan impeller made of highstrength steel. Engineering Failure Analysis. 2021;127:105502.

31. Kaščák L., Cmorej D., Spišak E., Slota J. Joining the high-strength steel sheets used in car body production. Advances in Science and Technology Research Journal. 2021;15(1):184-196. 
32. Jimenez-Martinez M. Fatigue of offshore structures: A review of statistical fatigue damage assessment for stochastic loadings. International Journal of Fatigue. 2020;132:105327.

33. Nykyforchyn H., Zvirko O., Dzioba I., Krechkovska H., Hredil M., Tsyrulnyk O., Student O., Lipiec S., Pala R. Assessment of Operational Degradation of Pipeline Steels. Materials. 2021;14:3247.

34. Carpenter K.R., Dissanayaka P., Sterjovski Z., Li J., Donato J., Gazder A.A., van Duin S., Miller D., Johansson $\mathrm{M}$. The effects of multiple repair welds on a quenched and tempered steel for naval vessels. Welding in the World. 2021.

35. Łabanowski J., Fydrych D., Rogalski G., Samson $\mathrm{K}$. Underwater welding of duplex stainless steel. Solid State Phenomena. 2012;183:101-106.

36. Charziioannou K., Karamanos S.A., Huang Y. Ultra low-cycle fatigue performance of S420 and S700 steel welded tubular X-joints. International Journal of Fatigue. 2019;129:105221.

37. Vuorinen A., Hosseini N., Hedayati A., Kornacker E., Fernandez M.T., Sanz J., Gonzalez M.I., Canibano E. Mechanical and microstructural evolution of high performance steel (S700MC) for road restraint systems. Engineering Failure Analysis. 2020;108:104251.

38. Moravec J., Sobotka J., Novakova I., Bukovska $\mathrm{S}$. Assessment the partial welding influences on fatigue life of S700MC steel fillet welds. Metals. 2021;11:334.

39. Kik T., Górka J., Kotarska A., Poloczek T. Numerical verification of tests on the influence of the imposed thermal cycles on the structure and properties of the S700MC heat-affected zone. Metals. 2020;10:974.

40. Górka J. Assessment of the weldability of T-welded joints in $10 \mathrm{~mm}$ thick TMCP steel using laser beam. Materials. 2018;11(7):1192.

41. Górka J., Stano S. Microstructure and properties of hybrid laser arc welded joints (laser beam-mag) in thermo-mechanical control processed S700MC steel. Metals. 2018;8(2):132.

42. Skowrońska B., Chmielewski T., Golański D., Szulc J. Weldability of S700MC steel welded with the hybrid plasma + MAG method. Manufacturing Review. 2020;7:4.

43. Szymczak T., Makowska K., Kowalewski Z.L. Influence of the welding process on the mechanical characteristics and fracture of the S700MC high strength steel under various types of loading. Materials. 2020;13:5249.

44. Węgrzyn T., Szymczak T., Szczucka-Lasota B., Łazarz B. MAG welding process with micro-jet cooling as the effective method for manufacturing joints for S700MC Steel. Metals. 2021;11:276.

45. Świerczyńska A., Landowski M. Plasticity of BeadOn-Plate Welds Made with the Use of Stored FluxCored Wires for Offshore Applications. Materials. 2020;13:3888.

46. Tomków J., Fydrych D., Wilk K. Effect of electrode waterproof coating on quality of underwater wet welded joints. Materials. 2020;13(13):2947.

47. Njock Bayock F., Kah P., Mvola B., Layus P. Effect of Heat Input and Undermatched Filler Wire on the Microstructure and Mechanical Properties of Dissimilar S700MC/S960QC High-Strength Steels. Metals. 2019;9:883.

48. Henzler W., Sawa M., Trębicki P., Szala M., Winiarski G. Influence of austenitic interlayer on the properties of stellite padding welds after impact-hardening. Welding Technology Review. 2021;93(2):13-20.

49. Zima B., Kędra R. Detection and size estimation of crack in plate based on guided wave propagation. Mechanical Systems and Signal Processing. 2020;142:106788.

50. Tomków J., Fydrych D., Rogalski G., Łabanowski J. Temper bead welding of S460N steel in wet welding conditions. Advances in Materials Science. 2018;18(3):5-14.

51. Aloraier A.S., Joshi S., Price J.W., Alawadhi K.H.A.L.E.D. Hardness, microstructure, and residual stresses in low carbon steel welding with post-weld heat treatment and temper bead welding. Metallurgical and Materials Transactions A. 2014;45(4):2030-2037.

52. Surojo E., Wicaksana N.I., Saputro Y.C.N., Budiana E.P., Muhayat N., Triyono T., Prabowo A.R. Effect of Welding Parameter on the Corrosion Rate of Underwater Wet Welded SS400 Low Carbon Steel. Applied Sciences. 2020;10:5843.

53. Szala M., Szafran M., Macek W., Marchenko S., Hejwowski T. Abrasion resistance of S235, S355, C45, AISI 304 and Hardox 500 steels with usage of garnet, corundum and carborundum abrasive. Advances in Science and Technology Research Journal. 2021;13(4):151-161. 